\section{Electroconvulsive therapy (ECT) effective for psychotic recrudescence and suicidality after varenicline adjunctive therapy for smoking cessation in a schizoaffective patient}

\section{Eletroconvulsoterapia efetiva para recrudescimento psicótico e suicidalidade após terapia adjuntiva com vareniclina para cessação de tabagismo em paciente esquizoafetivo}

\section{Dear Editor,}

Schizoaffective patients present the highest rates of smoking and heavy smoking among all diagnostic groups, including schizophrenia and bipolar disorder. ${ }^{1}$ Smoking cessation is a major treatment objective, but many patients experience difficulties and relapse. Adjunctive pharmacotherapy with varenicline brings new hopes.

A 56-year-old schizoaffective obese woman, with arterial hypertension and mild chronic obstructive pulmonary disease was frustrated in previous attempts to quit smoking, either with the aid of psychosocial treatment alone or combined with nicotine gum and patch. Bupropion had to be discontinued due to the irruption of manic symptoms. Her mother had bipolar I disorder. From age 18 (first psychiatric hospitalization), haloperidol was the main antipsychotic drug for thirty years. She did not want to quit during these initial years, and smoked up to 100 cigarettes per day. Adherence to psychiatric treatment was incomplete, with eight lifethreatening suicide attempts. In subsequent years, haloperidol was substituted for lithium plus ziprasidone, improving compliance and stability. Thirty months later, she started to express a desire to quit cigarettes. Varenicline was titrated from $0.5 \mathrm{mg}$ once a day to $1 \mathrm{mg}$ twice a day, and the first month passed with only minor mood changes. In the second month, the following escalating mixed symptomatology built up rapidly: increased energy, logorrhea, grandiosity, irritability, impulsivity, voices commenting on her, paranoid ideation, nihilistic ideas about the future, intense selfcriticism, frequent crying, and continuous suicidal ideation, with a specific plan. She recovered with 6 bilateral, bitemporal ECT sessions. As for the consequences attributable to varenicline, she later evaluated such treatment as highly beneficial and valuable to her health. She now completed two years of tobacco abstinence. Varenicline-aided smoking cessation treatment may have had a role in triggering psychotic recrudescence and suicidal behavior.

Current smoking, smoking cessation, and medications for smoking cessation (bupropion, rimonabant, and varenicline) were all previously associated with suicide. ${ }^{2}$ Schizoaffective disorder is also significantly associated with suicide. Cigarette smoking decreases serotonin turnover and inhibits brain monoamine oxidase, increasing impulsivity and suicidality in a recently abstinent schizoaffective patient. Mood improving and antidepressant augmenting properties of varenicline have been previously described, ${ }^{3}$ and such a drug might concur to generate unstable mood. Particular vulnerabilities to nicotine, nicotine abstinence, and varenicline might be determined by variants of the nAChR gene recently found in schizoaffective disorder, ${ }^{4}$ which might favor fast built up of impulsivity and suicidality with varenicline use. GABA-A receptor beta subunits, GABRB 4 and GABR1, could also be envolved. ${ }^{5}$

According to the American Psychiatric Association, ECT is currently the best treatment for a rapid response to psychosis or suicidality. In spite of this, ECT has no visibility in the literature of smoking cessation treatments. We recommend that ECT be considered for psychotic recrudescence and suicidality in the context of varenicline adjunct therapy for smoking cessation in schizoaffective patients.

Almir Ribeiro Tavares
Universidade Federal de Minas Gerais (UFMG), Belo
Horizonte, BH, Brazil

Fernando Madalena Volpe

Fundação Hospitalar do Estado de Minas Gerais (FHEMIG), Hospital Galba Velloso, Belo Horizonte, BH, Brazil 


\section{Disclosures}

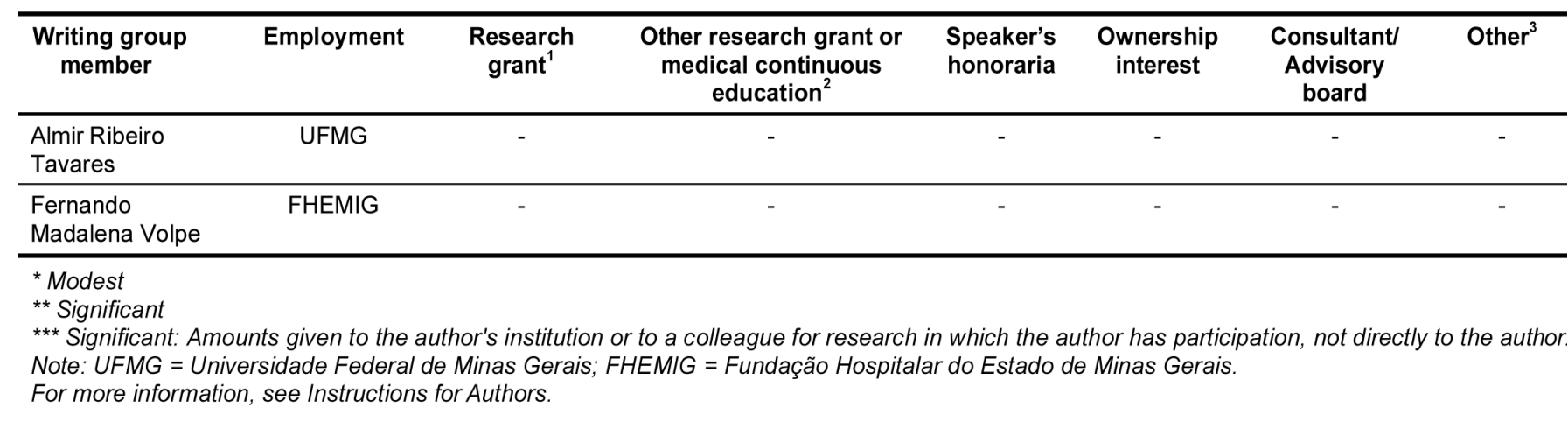

References

1. Vanable PA, Carey MP, Carey KB, Maisto SA. Smoking among psychiatric outpatients: relationship to substance use, diagnosis, and illness severity. Psychol Addict Behav. 2003;17(4):259-65.

2. Hughes JR. Smoking and suicide: a brief overview. Drug Alcohol Depend. 2008;98(3):169-78.

3. Philip NS, Carpenter LL, Tyrka AR, Whiteley LB, Price LH. Varenicline augmentation in depressed smokers: an 8-week, open-label study. J Clin Psychiatry. 2009;70(7):1026-31.

4. Martin LF, Leonard S, Hall MH, Tregellas JR, Freedman R, Olincy A. Sensory gating and alpha-7 nicotinic receptor gene allelic variants in schizoaffective disorder, bipolar type. Am JMed Genet B, Neuropsychiatr Genet. 2007;144(5):611-4.

5. Craddock N, Jones L, Jones IR, Kirov G, Green EK, Grozeva D, Moskvina V, Nikolov I, Hamshere ML, Vukcevic D, Caesar S, Gordon-Smith K, Fraser C, Russell E, Norton N, Breen G, St Clair D, Collier DA, Young AH, Ferrier IN, Farmer A, McGuffin P, Holmans PA; Wellcome Trust Case Control Consortium (WTCCC), Donnelly P, Owen MJ, O'Donovan MC. Strong genetic evidence for a selective influence of $\mathrm{GABA}_{\mathrm{A}}$ receptors on a component of the bipolar disorder phenotype. Mol Psychiatry. 2010;15(2):146-53. 